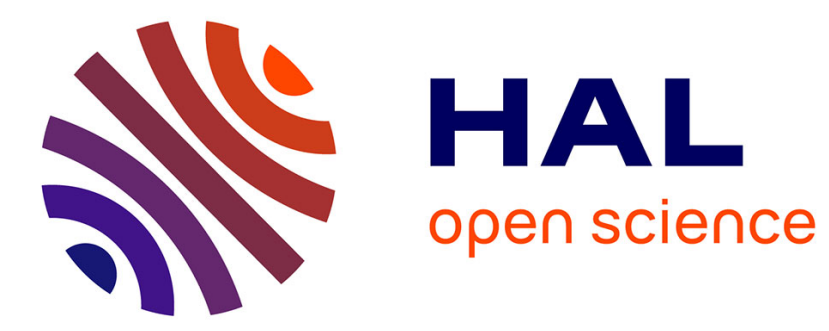

\title{
Differentiating farmers: opening the black box of private farming in post-Soviet states \\ Lee-Ann Sutherland
}

\section{To cite this version:}

Lee-Ann Sutherland. Differentiating farmers: opening the black box of private farming in post-Soviet states. Agriculture and Human Values, 2009, 27 (3), pp.259-276. 10.1007/s10460-009-9212-y . hal00509660

\section{HAL Id: hal-00509660 \\ https://hal.science/hal-00509660}

Submitted on 14 Aug 2010

HAL is a multi-disciplinary open access archive for the deposit and dissemination of scientific research documents, whether they are published or not. The documents may come from teaching and research institutions in France or abroad, or from public or private research centers.
L'archive ouverte pluridisciplinaire HAL, est destinée au dépôt et à la diffusion de documents scientifiques de niveau recherche, publiés ou non, émanant des établissements d'enseignement et de recherche français ou étrangers, des laboratoires publics ou privés. 


\title{
Differentiating farmers: opening the black box of private farming in post-Soviet states
}

\section{Lee-Ann Sutherland}

Accepted: 13 February 2009

\begin{abstract}
This paper addresses the question of farmer objectives associated with private farming in Eastern Europe. Drawing on qualitative interviews with private farmers in Bulgaria and southern Russia, the instrumental objectives of business development and job-replacement consistent with recent literature are demonstrated, but also intrinsic, social, and personal objectives, such as enjoyment of agricultural production, desire for independence, and proving oneself. These objectives are described in relation to associated farm size, investment practices, and succession plans, resulting in five idealized farming types which are similar in the two study states: agribusinessmen, primary farmers, pluriactive farmers, reluctant farmers, and minority horticulturalists. It is argued that differences in farming objectives have important implications for farming longevity and succession, opening up a research agenda for the study of private farming in post-Soviet states.
\end{abstract}

Key words Farming typologies - Farming styles - Post-Soviet agrarian change - Russian agriculture $\cdot$ Bulgarian agriculture

L. Sutherland (email)

Macaulay Land Use Research Institute, Craigiebuckler, Aberdeen, AB25 8QH, United Kingdom Email: $\underline{\text { 1.sutherland@macaulay.ac.uk }}$

\section{Author Biography}

Lee-Ann Sutherland (née Small) is a social scientist at the Macaulay Land Use Research Institute in Aberdeen, Scotland, where she recently completed post-doctoral research on the role of farmers' social networks in decision-making processes. This paper is based on her $2005 \mathrm{PhD}$ 
work at the University of Aberdeen, on the topic of agriculture-based livelihood strategies in Bulgaria and southern Russia.

\section{Differentiating farmers: opening the black box of private farming in post-Soviet states}

You understand, it's a condition of the soul, if you don't love land, then a lot of people worked for a year or two and quit. Like drugs to a drug addict, for the farmer it is land, it's a passion. Every day here, problems, problems, but it's a passion, a hobby. Lena, you know that if I quit, the next day I would have a stroke. You understand, it's a narcotic.

Private farmer "Pasha," Krimsk Rayon, Russia

\section{Introduction}

Pasha is one of the new private farmers in Russia, operating a 250 hectare mixed vegetables and cereals farm in partnership with two other farmers. Pasha was 31 at the time of the study, and started his farm immediately after graduating from university ten years previously. What is important about his statement above, a response to the question of why some people became private farmers but others did not, is that he describes his passion for farming and the central role it plays in his life. This is far from the rational economic actor responding to institutional and social constraints as portrayed in structural analyses of private farming in Eastern Europe (EE). Addressed here is the question of individual farmer objectives for initiating and continuing their farm businesses, and the implications of patterns in responses for the long term structure and viability of private farming in $\mathrm{EE}$.

Private farming in post-Soviet states is well into its second decade. Collectivized agriculture has demonstrated remarkable resilience, and private farming has remained somewhat 
marginal in Russia, where in 2006 it occupied only 13\% of agricultural land (Federal Office of State Statistics 2006). This pattern is common in the Commonwealth of Independent States (CIS) (12 former Soviet republics, excluding the Baltic states); Lerman et al. (2004) demonstrated that only about $21 \%$ of agricultural land is in individual use in the CIS, whereas $66 \%$ is under individual management across Central and Eastern Europe. In light of this, recent academic work has focused quite usefully on the resilience of collectivized agricultural production, and the internal dynamics and external circumstances that have made survival of these enterprises possible (Kalugina 2002; Spoor and Visser 2004; Sutherland 2008). However, although academics are recognizing that the business orientations of managers of privatized collective farms and newly formed cooperative farms differ considerably from those of private farmers (Davydova and Franks 2006; Kaneff 1998), little work has been done on the approaches to agricultural engagement adopted by private farmers. This research represents an initial step in that direction.

The slow development of private farming in the 1990s was unexpected by Western observers, who had been anticipating the collapse of the collectivized system and emergence of commercial household or family farming, bringing with it the advent of efficient post-Soviet agrarian systems (Ellman 2003). Bezemer (2002) argued that these assumptions were based on methodological individualism, with rationality as the leading behavioral motive: new land owners would seize the opportunity to maximize income from their holdings through the establishment of private farms. Institutions and culture were given very little consideration in initial predictions. As a result, predominantly production-based concerns have informed research into private farming and large farm transition, whereas studies of home production or "people's farms" have utilized ethnographic or sociological approaches (Pallot and Nefedova 2003, p. 347).

In recent literature surrounding the nature of private farming in EE, private farmers tend to be viewed homogeneously as either entrepreneurs or survivalist peasants. Wegren, O'Brien, and Patsiorkovski describe the new farmers as the former, a "special breed of people: independent, brave, entrepreneurial, and dedicated" (2002, p. 6), who are most likely of the new agricultural producer types to consider themselves "winners" in the post-Soviet agrarian reforms. However, the number of extremely small-scale private farms in EE has sparked discussion about whether individual farming actually represents hidden unemployment (Lerman et al. 2004). 
Allina-Pisano (2004) provides a social structural analysis of this dichotomy, arguing that the farmers in her Russian and Ukrainian study represent polar extremes of the social spectrum: those so high in the social hierarchy that land acquisition was not difficult, and those already so marginalized that accessing land did not pose a threat to local village culture. While AllinaPisano's work is an important step in investigating social aspects of private farm formation and differentiation, Pasha's statement, and indeed those of many of the farmers in this study, indicate that more personal rewards also play an important role. The importance of individual objectives is also supported by an extensive literature on family farming in the West, which describes a wide variety of approaches to farming and resultant differential response to markets and policy initiatives (e.g., Shucksmith and Hermann 2002). Identification of approaches to private farming in EE can be expected to result in similar types of conclusions.

This paper is based on findings from a comparative case study of agricultural producers in four regions in Bulgaria and southern Russia. In this study it was found that private farmers in both countries identified what could be considered self-actualizing objectives alongside more pragmatic economic concerns of providing income for their households. The existence of these objectives raises the question of personal agency influences on the trajectory of private farming in the study states. What were the objectives for becoming private farmers? What are the current objectives for the farm? How do these differ between study states? How do these objectives reflect other attributes of the farm business such as scale and investment patterns? What implications do these have for the development of private farming in the study states? These are the questions addressed here.

\section{Agrarian objectives and values in Eastern Europe}

As discussed in the introduction, in the recent EE literature agricultural producers are typically characterized by their apparent economic rationales: entrepreneurs or un- or underemployed individuals seeking additional income. However, few researchers have actually asked the new EE private farmers why they became farmers. Kopeva et al. (2003) are an exception: their study in Bulgaria found that there are different reasons for engaging and disengaging from farming: engaging as a last resort and disengaging to move into less labor intensive or more lucrative 
occupations when they become available. As such, Kopeva et al.'s work supports the conception of private farmers as underemployed, farming their restituted land because they have few other options to generate resources to support the household. Kopeva et al.'s work focused on current farming objectives, finding that the primary objectives for the farm were to maximize income and secure a standard of living, although providing for the next generation was also identified as highly important by farmers in areas of low agricultural production. Objectives of private farming identified in Kopeva et al.'s study are thus solely economic.

Self-provisioning in village gardens and urban allotments has a lengthy heritage across $\mathrm{EE}$, and there is a substantial literature on the commodification of traditional social practices of household exchange in the post-Soviet period (see Chevalier 2001; O'Brien and Patsiorkovski 2006). Brown and Kulcsar's (2001) work in Hungary utilized an "embeddedness perspective," arguing that there are both economic and social logics to engagement in agricultural production at the household level, and that understanding of social relationships is essential to understanding economic behavior. Social objectives and values identified by Brown and Kulcsar (2001) include hobby, social norm, ability to help neighbors, potential to work at home and opportunity to be one's own boss, with coexisting economic objectives of tax-free income, absence of other job alternatives, and opportunity to earn money.

There has been some work done on individual objectives associated with other agrarian forms in EE. The social objectives of managers of post-Soviet collective agrarian forms (privatized collectives in Russia, reorganized cooperatives in Bulgaria and elsewhere in EE) are well known, and demonstrated through on-going support to village services (Davydova and Franks 2006; Kaneff 1998; Gambold-Miller 2003). In her study of agricultural employees in Russia, Sutherland (2008) found a combination of economic and personal incentives reinforcing ongoing agricultural employment on privatized state and collective farms. These included: socialized expectations and benefits of white- or blue-collar employment, regular hours, vacation, pensions, career advancement and enjoyment of village life, reflecting an "employment culture" of large enterprise engagement which has carried on from the Soviet period.

Multiple objectives have also been associated with land acquisition in EE: Wegren and Belen'kiy (2002) analyzed findings from the Russian Center for Public Opinion surveys of 1995-6 and 1997-8, and found that the most common motivation for obtaining agricultural land (rental or purchase) was for the production of agricultural products intended for consumption, 
followed by family relaxation, construction of a country home, and commercial agriculture. These objectives are consistent with findings by Pallot and Nefedova (2003, p. 361), which identify a continuum of approaches to small-scale production (both home production and private farming), ranging from recreational gardening to accumulation. This paper explores the personal and economic objectives of large- and small-scale private farmers in Bulgaria and southern Russia, relating these to farm structural characteristics.

\section{Objectives and values of Western family farmers}

The majority of literature on objectives associated with agricultural production is found in the Western family farming literature. It has been argued that the Western literature can provide a useful foundation for studying agrarian change in post-Soviet states (see Small 2007) and a useful point of comparison for post-Soviet farms (Pallot and Nefedova 2003). Although private farming in $\mathrm{EE}$ and the West has developed from different foundations, and therefore can be expected to present differently, similar issues surrounding the dependence of individual farming on land, family labor, and fluctuating economic returns can be expected to result in some similarities. In addition, the conceptual work addressing Western family farming is much more developed than that on private farming in EE, largely because of its longevity as an agrarian form and thus as a topic of study. Two particular concepts from the Western literature are important to this study: the multiple objectives of farming households, and the different types of approaches to farming.

Farm households in the West have long been recognized as "satisficing" (see Simon 1957): seeking a solution which satisfies their own objectives, in line with the limits of their environment and their own assessment of the situation, rather than seeking solely to maximize profits (Gasson and Errington 1993). This reflects the combination of family and farm, which Gray (1998) conceptualizes as "consubstantial" - so mutually entwined that it is meaningless to evaluate the two separately. Gasson and Errington (1993) outline a categorization of farming objectives based on previous work by Gasson (1973) in the UK: 
- Instrumental: maximizing income, making a satisfactory income, securing income for the future, avoiding losses, increasing net worth, controlling a larger business, providing pleasant working conditions

- Intrinsic: enjoying the work itself - individual tasks, variety etc., pursuing a healthy, outdoor life, purposeful activity, value in hard work, independence - free from supervision, free to organize time in a variety of situations

- Social: belonging to the farming community, gaining recognition, prestige as a good farmer, creating and maintaining good relations with workers, continuing the family tradition, spending more time with family

- Personal: exercising special abilities and aptitudes, chance to be creative and original, gaining self-respect for doing a worthwhile job, meeting a challenge, achieving an objective, self-fulfillment and personal growth (Gasson and Errington 1993, p. 99)

Consistent with the satisficing principle, Gasson and Errington (1993) argue that farmers act to achieve several of these objectives, which often shift over the life-course in reflection of the changing needs of the farm family.

The Western literature also supports the argument that farmers are heterogeneous in their approaches to farming. A review of the literature on Western agriculture reveals at least a dozen separate typologies of farm and operator types. Examples include work by Whatmore et al. (1987a, b) and Marsden et al. (1992) who utilize varying degrees of subsumption - the integration of external capital into the enterprise - to define types of farmers. Salamon (1985) identified yeoman versus entrepreneurial types, based on ethnicity, business orientation, and response to risk. Bowler et al. (1996) offered a classification of seven possible pathways of farm business adjustment, based on productivism, diversification, pluriactivity, and traditional farming ideals. Shucksmith and Herrmann (2002) utilized Bourdieu's concept of habitus, or "disposition to act" as a major factor in farm household decision making. In their study of British farmers, they identified six types of farmers, on the basis of shared background, beliefs, and farm type. What these typologies have in common is the assumption that the approaches farmers take to their businesses differ, and that these differences in objectives impact on market integration and 
responses to economic risk and policy shifts, with implications for agrarian change and the longterm viability of the individual types.

The number of Western farming typologies demonstrates that there is no single accepted typology of farming styles. Indeed, Van der Ploeg (1994) - perhaps the best known of the farming typologists - argues that farming types are region specific and best defined by the farmers themselves. Criticism of his work - that the types exist in the researcher's mind, and are in fact artifacts of the methodology (Howden and Vanclay 2000) - could equally be applied to other typologies. For most academics, farming typologies are a tool for illustrating differences in presentation, and anticipating differences in response, rather than a representation of "reality." This is consistent with the social constructionist perspective utilized in this study: "the making and remaking of society through the ongoing self-transforming actions and perceptions of a diverse and interlocked world of actors" (Long 2001, p. 1). As such, the emphasis in this research is on the perceptions of private farming expressed by study respondents, and how these are borne out in the characteristics of their farming operations, rather than construction of a definitive typology of private farming approaches.

In this paper, the values and objectives of private farmers are organized under Gasson and Errington's (1993) four headings as a means of identifying the range of values and objectives associated with private farming and how these differ between the two case study states. These rationales are then placed in the context of corresponding farm characteristics, resulting in five idealized types, from which issues for the long-term development of private farming are drawn for discussion.

\section{Methods}

This paper is based on qualitative field research with current and former private farmers in Bulgaria and Krasnodar Territory (Russia), undertaken in 2002-2003. The research approach was inductive, due the very limited data previously available on the non-economic objectives of private farmers. Qualitative research is typically inductive, with an interpretivist epistemology and a constructivist ontology (Bryman 2001). Interpretivism stresses the understanding of the social world, through an examination of the interpretation of that world by its participants 
(Bryman 2001, p. 264). Constructivism views social properties as outcomes of the interactions between individuals. Interpretivism and constructivism are thus consistent with Long's actororiented approach, utilized as an ontological position for the study.

Long (2001) constructs actors as knowledgeable and creative, but their actions shaped by routine, social conventions, and power relations. From Long's (1997) perspective, agriculture is a social construction. It is a negotiated process involving specific actors. Conflicts occur between actor projects or agendas, resulting from differential access to resources, opportunities for investment or accumulation, and accommodation of different bodies of knowledge and practice, resulting in specific patterns of behavior. Agrarian change occurs as a result of these conflicts or negotiations between actors, rather than as a result of structural transformations. Markets and technology therefore do not determine how farming is carried out, but provide the context in which different positions are possible, constituting "room for manoeuvre" (van der Ploeg 1994, p. 9). In studying commodity relations, Long's (1997) interest is in how particular values - such as economic rationality - become internalized in specific populations. Long stresses that this is never absolute - social values are negotiated on an ongoing basis, reflecting multiple images and symbols, as much as the search for material gain. This study used as primary data the rationales given by private farmers in the study site for their decisions to become private farmers, and their stated objectives for their farming operations.

Study interviews took place in four regions: Plovdiv and Dobrich regions in Bulgaria, and Krimsk and Pavlovsky Rayons in Krasnodar Territory (see Figure 1). The regions were loosely matched geographically to ensure that differences observed between countries were not reflecting differences in commodity production: Dobrich and Pavlovsky are both largely cereal producing regions, whereas Plovdiv and Krimsk regions have more mixed farming, particularly vegetable and meat production. Interview respondents were selected through a stratified snowball technique, which emphasized identification of a wide variety of private farmers (based on scale of production, business organization, and farmer age), rather than a representative sample, which would have resulted in the inclusion of almost entirely small-scale producers, particularly in Bulgaria. As is typical of qualitative research, findings are not intended to be representative of the study sites, but to reflect the variety of experiences and perspectives therein.

(Figure 1 about here). 
Interviews were conducted utilizing a question guide, which evolved over the course of the research. Topics included the organizational structure and scale of the farming operation, commercial orientation, market knowledge, agrarian ideology, work history, future and succession plans, what makes for a "good farmer," and rationale for initiating a private farm. In Russia, interviews were conducted in Russian by the author, recorded and then transcribed. In Bulgaria, interviews were conducted with a translator, and notes taken in English. Data was analyzed qualitatively by the researcher, through the construction of "livelihood profiles," organizing respondent statements under topical headings as a form of qualitative data coding. These headings are listed in Appendix A. Demographic characteristics of the respondents were also entered into SPSS statistical software, in order to monitor the variety of respondents in the study.

Qualitative interviewing is particularly useful for studying complicated relationships and slowly evolving events or processes (Rubin and Rubin 1995), and thus is particularly appropriate to this type of exploratory study of approaches to private farming in the study states. However, there is much dispute over the degree to which measures of reliability and validity - the hallmarks of quantitative research - can be applied to qualitative work. This study utilized triangulation - the use of multiple sources of data - to corroborate data and findings (Bryman 2001). Data were drawn from both key informants and private farmers, and then compared to existing literature for consistency. This literature is presented in the text alongside research findings. The implications of new findings are discussed, with recommendations for subsequent quantification as appropriate. Generalization from qualitative research is also a subject of debate, in that findings are not based on representative samples. Mason (2002) argues that qualitative research can be generalized, to the extent that concepts and theories generated from the research should have relevance beyond the study site, even if the precise data cannot be replicated. In this study, a broad range of private farmers were sought from across the four study sites. The typology based on these findings is not intended to be definitive, but to raise issues underlying decisions to become private farmers and identify the potential impact of personal and intrinsic farming objectives on business progression.

In total, data were drawn from interviews with 63 current private farmers: 38 Bulgarian and 25 Russian. Sixteen interviews with members of local and regional administrations were 
utilized to provide further insights and contextualization. The number of full-time farmers (defined as individuals who spend the majority of their working time on the farm) interviewed was almost equal between the two states: 22 Russian and 21 Bulgarian. However, the more flexible legal status of farming in Bulgaria is reflected in the much higher number of part-time farmers in the Bulgarian study (17). Ages of Bulgarian farmers ranged from 25 to 80 and Russians from 15 to 65, but in both cases, the majority of farmers were in their forties or fifties. All but six of the private farmers (two Russian and four Bulgarian) were male. This is characteristic of the private farming population, which is predominantly male in both study states. It is important to note that a significant percentage of the new private farmers were not former agricultural employees. In this study, only 22 of the 63 (seven Bulgarian and 15 Russian) had work experience in collectivized agriculture. This is supporting by findings from Ioffe and Nefedova (1997), who found that over half of the initial private farmers in Russia were exurbanites. The restitution of land to its original owners in Bulgaria led to a high number of urbanites receiving land, and this is reflected in the lack of formal agricultural work experience of most Bulgarian farmers in the study. However, the vast majority of study respondents from both study states had informal agricultural work experience cultivating village gardens or urban allotments.

\section{Study sites}

In this study, case studies were undertaken in two post-Soviet "states": Krasnodar Territory, Russia, and Bulgaria, reflecting the research purpose of identifying a range of approaches to engagement in private farming. Prior to 1990, Bulgaria and Russia had very similar agricultural structures: large-scale state and collective farms, with provision for household production usually restricted to plots of less than 1 ha within the territory of the village. The state and collective farms of both countries had maintained their size from a "scaling up" process in the early 1970s, when government policy in both countries dictated the amalgamation of smaller, typically single village collective farms into complexes that engulfed entire municipalities. Decentralization reforms in Bulgaria in the 1980s encouraged the sale of production from home gardens, and in some areas rental plots from the collective farms, resulting in what could be construed as tiny 
private farms (Meurs and Djankov 1998). This initiative was abandoned in the formal privatization reforms of the 1990s.

A review of Krasnodar Territory's agricultural production statistics reveals a dramatic decrease in all commodities in the early 1990s, often to as low as $10 \%$ of previous levels. Although this was starting to rebound, current production levels were at approximately two thirds of 1990 levels in the study sites at the time of the study (Goskomstat 2002). The same pattern holds true for Bulgarian production levels (BNSI 2003). However, agriculture continues to be important in the economies of Krasnodar Territory and Bulgaria, due to the decline in other industries.

As is characteristic of most of EE, Bulgaria engaged in wholescale land privatization and agricultural restructuring in the early 1990s. The collective and state farms were disbanded, and land, equipment, and livestock privatized by restitution to the owners, or their heirs, of the late 1940s. In essence "what you put in, you got out," in terms of land and equipment. Bulgarian inheritance laws divide land equally among all heirs, a feature that was already resulting in land fragmentation in the 1940s. At the time of collectivization in the 1940s, there were approximately one million private family farms spread across 12 million plots of land (each plot averaging only 0.4 ha), but only about 200 large-scale private farms of over 50 ha in size (Dobreva 1994, p. 340). Legislation in the early 1990s encouraged the formation of voluntary agricultural cooperatives, but land could also be farmed individually. As a result, 99\% of agricultural holdings by "natural persons" were less than 5 ha in size in 2003, and the number of these holders was estimated at 658,000 (NSPRD 2007). This has resulted in an extensive land rental market, which is characteristic of EE as a whole (Swain 2000). There are also 7000 agricultural holdings managed by legal entities, about 2000 of which are cooperatives. These cooperatives have been decreasing in number over the post-Soviet period (NSPRD 2007).

In contrast, the agrarian structures of Krasnodar Territory appear almost stable. As is characteristic of most of the former Soviet Union, collective and state farms (and the land they operated) were formally privatized through allocation of land and equipment shares to employees in the early 1990s (Lerman et al. 2004). Employees who wanted to attempt independent farming could withdraw between 2 and 5 ha of land, in addition to equipment, from the collective. Both former farm employees and other interested individuals could access land through a government 
pool created from the resizing of privatized state and collective farms. ${ }^{1}$ In the early $1990 \mathrm{~s}$, up to 100 ha was available through these pools. Recipients of both common-pool land and allocations from privatized collectives held legal title to the land, but with the proviso that the land was utilized for agricultural production; recipients risked losing title should they fail to meet local definitions of productive agriculture. At the time of the study, the number of independent farmers in Krasnodar Territory was approximately 19,000, in comparison to approximately 700 privatized state and collective farms (Goskomstat 2002).

The conditions for establishing private farms in the two study states are thus very different: in Krasnodar Territory, land shares were available to current or retired employees and had to be actively removed from the collective and/or applied for through a bureaucratic process. In Bulgaria, previous owners or their heirs received physical land through restitution, meaning that new owners did not necessarily have a personal interest or experience of agricultural production. Landowners in Bulgaria are also older (on average) than in Russia, as restitution was made to heirs, rather than employees. Initial land holdings were larger in Russia, although as will be demonstrated in this paper, the emergence of a land rental market in Bulgaria has allowed larger private farms to develop. In addition, for Bulgarians, it was possible to work full-time, sometimes on a reorganized cooperative farm, while initiating their own private farm, and thus offsetting farm expenses with their waged income. In Russia, private farming is an "all or nothing" venture. Withdrawing land from the collective or state farm effectively ended employment, and with few other local employment opportunities (and a legal requirement to produce significant agricultural produce or risk losing the land), households became immediately dependent on the new farm enterprise. In both countries, restituted or allocated resources from the collectivized system were insufficient to initiate a private farm. Further resource acquisition was necessary in order to secure the equipment and buildings necessary for farming beyond the household garden level. Allina-Pisano (2004) and Small (2005) both found that private farmers typically access many resources through informal means, particularly family connections.

\footnotetext{
${ }^{1}$ Collectives were resized using a calculation based on number of workers or pensioners and the county allowance for individual allocation. For example, in Pavlovsky Region, workers were allowed 5 ha. A collective farm of 500 workers would therefore be downsized to 2500 ha. The remaining would be added to the government pool.
} 


\section{Findings}

In this study, the term private farmer is defined on the basis of agricultural production with the primary intent to sell. This is an expansion on the legal definition of private farmers in Krasnodar Territory, where farmers are defined as individuals utilizing agricultural land for private production, and registration is a legal requirement. In Bulgaria, registration as a private farmer is voluntary, and as a result, definitions vary. The study definition differentiates private farmers from home producers, who produce primarily for family use (although they may sell the extra), on allotments within rural villages. However, this is more difficult to distinguish in Bulgaria, where the potential to access government subsidies has motivated very small-scale landholders to register as farmers. There are a number of very small-scale Bulgarian farmers in the study as a result. Private farms are more easily distinguished from collectives and cooperatives based on legal structure. Private farmers do not have shareholders or members, although they may have partners and employees.

Instrumental rationales

The expectation of both development professionals and academics in the early post-Soviet period was that the establishment of private farms would reflect the desire of agricultural employees to see the financial rewards of operating their own businesses (Lerman et al. 2004). This was indeed the case for some respondents, who expressed their desire to "have a business."

At that time I needed to do something - in this territory we have a lot of agriculture - I was looking for something - this worked for us ...we needed to do something, looked carefully at the situation, decided on equipment, started with just repairs, then started buying equipment. Four years ago we bought a lot of equipment - we couldn't buy land, but we could buy equipment...

Owner of machinery dealership and farm, Russia 
However, only three of the respondents (one Bulgarian and two Russian) reported doing an organized market assessment prior to starting production. Instead, respondents typically utilized a "trial and error" method of marketing, producing similar commodities to those of the local privatized collective or cooperative farms, and continuing to produce those for which they found markets. These individuals are thus not typically "entrepreneurial" in the sense that they are utilizing innovative markets (see Vesala et al. 2007), although private farming itself can be considered an innovative method.

Private farming was also constructed simply as a way of making a living. Several respondents stated that they initiated private farms because they lost their jobs and/or were unable to find alternative employment.

For us, simply, the kolhoz went bankrupt, and we're 50 years old with no way to live. We need to find something to do, we couldn't find jobs because they just want young people, we don't receive anything - our pension is still far away, I have five years, my husband has 10 years [before we can go on pension], and so we decided on farming.

Private farmer, Russia

Respondents indicated that when large enterprises and cooperatives disbanded, private farming - often in the form of expanded home production - became perceived as the only possible income source that would allow them to stay in the village. While this has been recognized in the literature in the characterization of private farming as a labor sink (Lerman et al. 2004) acting as "job replacement," the economic importance of the village residence to the household income is not typically recognized. Sutherland (2008) argued that agricultural employees are often tied to the home village as a source of housing and self-provisioning through the home garden; employment on a collective is economically a secondary concern. The same holds true for very small-scale farmers: even after the loss of local employment, the home garden and residence are important resources, leading them to seek self employment in smallscale agriculture, rather than relocating to seek waged employment elsewhere.

The preceding two rationales for starting private farms reflect the dichotomous conceptualization of private farmers in $\mathrm{EE}$ as either entrepreneurial business people or expanded home gardeners. What emerges from this study is that even among instrumental objectives, the 
distinction between being pulled into private farming by business motivations and being pushed by financial necessity is not as clear as it might first appear. Several of the Russian respondents indicated that they had realized that the collective on which they were working was going to go bankrupt, so they undertook private farming proactively:

Because the kolhoz was coming to an end; I'm by education an agronomist and all my life worked in agricultural production... at that time agriculture was falling apart, I understood that and immediately left while there was the opportunity to take land... I provide for myself, my family, and what is left I sell.

Private farmer, Russia

Becoming a private farmer was thus perceived as an active means of optimizing resources to ensure a standard of living for the household, rather than a passive reaction when no other choice was possible.

The situation was different in Bulgaria, where the cooperatives were dissolved and land restituted to the owners (or their heirs) of the 1940s. Although recipients could informally utilize their restituted land before formal ownership was recognized, timing for leaving the enterprise did not impact on the quality or quantity of land and other resources received. However, several of the respondents who had initially put their restituted land into a cooperative, reported removing it in the late 1990s because they were dissatisfied with the financial returns received. They initiated farming enterprises in order to optimize the return from their land resources.

Intrinsic rationales

Enjoying "working on the land" was a common theme particularly among Russian respondents in responding to the question of the characteristics of a good farmer. Bulgarians also identified "love of animals," reflecting the greater prevalence of livestock among the Bulgarian respondents. Simplicity of the lifestyle was also identified as a value in both study states. Pasha's business partner, in a separate interview, concurred that farming "isn't work, it's a way of life." A Bulgarian farmer also described the "gambling" characteristics of farming, expressing a 
preference for risk activities. Farmers in both countries identified appreciation for a good harvest. The specific aspect appealing to farmers thus varied between and within study states.

Several of the respondents identified childhood experiences as important to the development of the intrinsic values associated with farming.

After work he [father] went to the garden, immediately, our home was in the northern Kazakstan, and we had an orchard...there were lilacs, apricots and a vegetable garden. There were tomatoes, I don't know what else, he raised them himself in the house and then transplanted them, and even Bulgarian peppers, and I watched him do this from my childhood

Private farmer, Russia

Working alongside a parent or sibling frequently provided the experience respondents recounted when asked about how they became interested in agricultural production. This is also true of agricultural employees (Sutherland 2008), and respondents indicated that similar intrinsic objectives which had led them towards employment in collectivized agriculture subsequently led them into private farming. Some of the respondents also reported expanding Soviet-era hobbies (such as bee keeping or watermelon production) to form their farming enterprises. When these respondents lost their jobs or saw the opportunity of private farming in the 1990s, they drew on their experience and interests in establishing the new enterprises. What began as activity with purely intrinsic satisfaction thus became a resource for meeting instrumental objectives of business development or job replacement.

There appears to be a reciprocal nature to the relationship between intrinsic enjoyment of production and the economic viability of the farm enterprise: intrinsic objectives were more apparent when the farm was deemed a financial success. Several of the farmers commented on their awareness of higher profitability in other industries, but stated that they initiated farms because of their enjoyment of agricultural production. Alternately, several respondents (from both countries) commented that they had no chance to feel pride in their work when they work so hard in comparison to other people who make more money. This is consistent with sociology of work literature (Noon and Blyton 2002), where satisfaction with work is linked to intrinsic factors, whereas dissatisfaction is related to instrumental factors such as low wages. Intrinsic 
objectives of production also seem to be something that can develop over time for private farmers. Several of the longest-term private farmers commented that when they began, they were primarily motivated by profit, but now very much enjoy the lifestyle. Others, who reported starting their farms in order to have a business, now approach it as a job because of a lack of financial success and an inability to find other work.

Social rationales

Respondents did not identify the social aspects of becoming a private farmer as part of their decision rationales. They did not comment on changes in social status, the social norms associated with breaking the status quo, or the stigma associated with manual labor, although these have been identified in the literature on EE (Kaneff 1998; Hivon 1998). Neither did they identify a sense of social responsibility as part of their rationale, although this has been well established as important to the social identity of many privatized collective and cooperative farm managers (Kaneff 1998; Kalugina 2002; Sutherland 2008). However, in this study, private farmers in both study states reported providing money or services in support of local needs, such as infrastructure and social programs. This was also found among large-scale private farmers by O'Brien and Patsiorkovski (2006) in Russia. Kaneff (1998) found that most residents in her study of the village Talpa, Bulgaria, associate land management with social and political responsibility rather than economic gain. Contribution to the village appears to be a social expectation of local businesses in both study states, including both privatized collectives and cooperatives, but excluding smaller-scale home provisioning units.

Consistent with Allina-Pisano's (2004) argument about the importance of social position to land acquisition, it was not unusual for people of high social status, such as the local mayor or members of regional government, to be involved in private farming in the Bulgarian sites. This was not legally possible in Krasnodar Territory, although one key informant commented that this does unofficially occur. Similarly, there was evidence for private farmers being among the socially marginalized. With the exception of Pavlovsky Rayon in Russia, the other study sites all had significant ethnic minority groups engaged in agricultural production: Korean and Turkish in Krimsk Rayon, and Turkish and Roma in Bulgaria. This is consistent with the identification of 
Korean agricultural groups in Pallot and Nefedova's (2007) work in Krasnodar Territory. The ethnic groups represent specific subsets of the population and are not fully integrated into the otherwise "white" population: in Krasnodar Territory, Turkish immigrants were allowed to purchase homes but not to register as residents and thus have no access to formal employment. Ethnic Korean groups worked their way across Russia to Krasnodar in the mid 1980s by renting land from collective farms and producing vegetables, a practice they still follow, living with their crops in the fields during the summer. In Bulgaria, Turkish and Roma groups have citizenship, but typically did not receive land in the restitution process. All of these groups produce vegetables intensively, relying primarily on manual labor. These groups represent distinct agricultural subcultures, continuing to operate within the new system. However, a number of farmers in this study from both states did not appear to belong to either the rural elite or an ethnic minority group, suggesting that social position is important but not completely limiting to becoming a private farmer.

Consistent with Kopeva et al. (2003), Bulgarian respondents did not usually identify a preference for rural life, although this was common among Russian respondents. Rural areas throughout EE have seen rapid declines in rural social service provision in the post-Soviet period. As a result, rural areas have not seen the "urbanization" - movement of urbanites into the countryside in pursuit of recreation and social amenities - characteristic of rural areas in the West (Swain 1999). Particularly in Bulgaria, there is a stigma associated with village life (Leonard and Kaneff 2002). As one key informant explained, moving to the city was viewed socially as a step forward; moving back to the village was a sign of failure. Although this was also true in Russia, most of the private farmers in the study were already located in the village prior to the collapse of communism, and so transition to farming did not involve relocation. Many of the new private farmers, particularly in Bulgaria, commute from the city to the village to work on their land, thereby continuing to access urban amenities - particularly education for their children. It is therefore possible to operate a farm without extensive interaction with the local village and thus circumvent (at least in part) local norms and social sanctions.

Personal rationales 
The importance of personal rationales was raised in the quote from Pasha, a Russian farmer, at the beginning of this paper. He described a passion for farming, and the addictive nature of the occupation. One of the six female farmers in this study, a Bulgarian from Plovdiv region, removed her land from the cooperative to farm it herself because she was not pleased with the rent she was receiving. Her stated motivation was the desire to "prove herself" - and prove to the local cooperative farm manager - that it was possible to make a success in agriculture. Several other respondents also focused on the aspects of proving themselves and increasing productivity as future objectives. Other farmers described farming as evidence of strength and willingness to take on risks and responsibilities.

I studied agriculture - I worked on the land all my life, and now I work on the land for myself. Why shouldn't I like it? I'm glad to work for myself.

Private farmer, Russia

Being independent was particularly important among respondents. This reflects their work experience in the Soviet system. Having been managed for years in their previous employment, they took the opportunity to start their own business and work independently, describing confidence in their own ability to make their business a success. Several commented on the problems they had observed in large agricultural enterprises, and were glad to be free of these, and carrying the weight of other, less competent employees. This individual responsibility and direct accountability was one of the reasons private farming was expected to become more efficient than the preceding collective system (Lerman 2003). However, the relatively large number of individuals able to become private farmers, but who did not, suggests that there were considerable disincentives to making this transition.

In my family, the traditions of agriculture are already strong, only nature or the government can make me quit.

Private farmer, Bulgaria

There was little current sense of honoring a heritage of private farming among respondents. While this is unsurprising among Russian respondents, where land collectivized 
before most respondents were born, it was also true in Bulgaria, where collectivization occurred in the 1940s and landholdings returned to the families. The only respondents to identify heritage as an important motivator for becoming private farmers were the oldest Bulgarian farmers, who had memories of their parents as farmers. They expressed regret that their children did not have the sense of connection to the family land that they themselves held. They attributed this to the lack of direct experience working on a family holding, which they believed to be fundamental to developing a sense of heritage. Although they were motivated to start their farms to continue their parents' legacies, they felt that they were too old, and that their children already had established (urban) jobs, thus leaving them without a successor, and therefore no reason to invest long term in the farm. Several of the younger private farmer respondents said that they hoped this would develop in their children with time, because farming is a major investment. However, there were also a number of farmers who planned for a successful enterprise for themselves, but who wanted "something better" - more financially lucrative and less work - for their children. They recognized that while private farming was self-actualizing for them, it might not be for their offspring. Pasha was a clear example of this, fulfilling personal objectives for himself, while preferring that his children achieve instrumental (economic) objectives.

\section{Relationship to farm attributes}

In this section, the relationship between ideological construction of farming and farm business characteristics is evaluated, utilizing examples of idealized "types" of farmers. In Russia, the size of the private farms ranged from 2 ha to 2000 ha, and in Bulgaria, from less than 1 ha to 3500 ha. While land base is not an absolute indicator of business size, it is useful as a descriptor, and allows reference to existing literature, which differentiates in large part based on scale and legal status of operations. Farmers were generally reluctant to discuss specific financial interactions in any case, most likely due to the considerable informal economies operating in the study areas.

To illustrate differences resulting from national contexts, patterns from Krasnodar Territory and Bulgaria are described separately. 
Bulgaria

In Bulgaria, 99\% of agricultural land holdings of "natural persons" (as opposed to other legal entities) are less than 5 hectares in size (NSPRD 2007). As a result, academic attention is drawn toward tiny farms, recognized by the state to represent people who see themselves as pensioners (55\%) or unemployed (15\%) (NSPRD 2007) and acting to supplement their incomes. In this study, these are termed reluctant farmers, to reflect clear stated preferences to not be engaged in producing and selling agricultural goods, and to avoid debates about the extent to which these individuals represent peasants (Kitching 1998; Clarke et al. 2000; Leonard and Kaneff 2002) or subsistence-oriented farmers (Caskie 2000; Kostov and Lingard 2002). However, within smallscale production, two other types can be identified: pluriactive farmers, who utilize restituted land to supplement household income from paid employment, and minority horticulturalists, who represent a distinct ethnicity-based cultural subtype. There are also a very small percentage of farmers operating at considerably larger scales, often termed renters due to the large amount of land they rent as part of their farming operation. These can be differentiated as agribusinessmen and primary farmers, on the basis of scale of production, business ownership, and social position. These distinctions are elaborated in this section.

Five of the Bulgarian farmers in the study can be termed agribusinessmen: large-scale farmers who own part of their land holding but rent land from several hundred other individuals, due to the small average size of individual land holdings. In this study, these farms ranged in size from 600 to 3500 hectares, employing between 10 and 100 people. These "farmers" are remarkable for several reasons. First, all of them had a second or third substantial business in addition to the farm. These included hotels and a seaside resort, grain storage and agricultural equipment dealerships, suggesting an entrepreneurial focus. Second, these business resources were accumulated in the 1990s during times of great economic instability. This suggests very strong informal ties, as argued by Allina-Pisano (2004); most had held advanced positions during the Soviet era such as senior agronomist or factory management ${ }^{2}$. There also may be linkages

\footnotetext{
2 All EE households can be expected to have a network of relations on which they draw for assistance, a carryover from years of working around extensive Soviet bureaucracies. It is therefore almost impossible to distinguish this historical practice of informal assistance from what Western observers would term 'mafia' connections. In the case of agribusinessmen, it was highly unlikely that they had amassed their resources as a result of waged employment or
} 
between them, suggesting similar social circles among the largest producers: the renter operating a 3500 hectare farm stated that he is one of 15 farmers of his size in Dobrich region, and 30 across Bulgaria as a whole, appearing acquainted with these farmers. Two others described efforts underway to organize cooperative input purchase or marketing of produce between the largest farms in their regions. Third, four of the five are investing in their multiple businesses with an intention of their children continuing operations; in most cases, these children were already involved in some aspect of the multiple businesses. While they uniformly identified instrumental objectives for their farms, several also identified intrinsic and personal objectives. Two of the agribusinessmen stated that they were aware that profits were higher in other industries but they preferred to stay in agriculture because they enjoy it, a third described farming as an "art" which he is still learning, but particularly enjoys.

Ten smaller-scale renters were also identified in the Bulgarian study, operating farms between 2 and 180 hectares in size. These are termed primary farmers, because they were notable for depending primarily on the farm as a source of household income, representing fulltime employment for the farmer (although the spouse may be employed off-farm), without other associated businesses. These farms also typically had one-two hired employees, who may be family members. Similar to agribusinessmen, they were positive about succession, actively including offspring in their businesses. Commodities were wide ranging - ducks, chickens, alfalfa, honey, orchards, green house vegetables, and milk in addition to the field crops, cattle, sheep, and pigs identified by the agribusinessmen. Farmers developed their operations from multiple points. Some had started their farms following job loss, others remained employed while starting their farm, and then discontinued paid employment to focus on the farm. A few had started their farms immediately after finishing formal education. Previous occupations included: accountant, airplane manufacturing, and employment on a cooperative farm. Motivations for becoming private farmers varied, but typically emphasized intrinsic and personal objectives: proving oneself, destiny, enjoyment of agricultural production, and independence.

personal investment, which suggests that their particular networks were exceptional in the amount of resources accessed, but no further conclusions can be drawn from the data. Due to the sensitivity of this issue, it was not possible to further evaluate the nature or extent of these relationships as a part of the study. 
A dozen study respondents from Bulgaria can be defined as pluriactive, in that they also had paid employment, typically on a full-time basis, in addition to their agricultural operation. ${ }^{3}$ Pluriactive farms were usually smaller scale than those of full-time farmers, but overlapped, largely reflecting the differences in commodities: two Dobrich area farmers produce field crops on 30 ha each on a part-time basis, whereas a full-time poultry operation with two employees could occupy only 2 ha. As such, farms in the pluriactive category ranged from 1 to 30 ha. They produced similar commodities to the range by full-time farmers, with the addition of lavender and pumpkins. Current occupations included: deputy mayor, school principle, chauffeur, train engineer, and full-time or seasonal employee on a cooperative. Within this group, only two had actively sought out additional land through rental; of these, only one had plans for expansion. The remainder could be considered "optimizers" in that they utilize the land restituted to them or already in their yards to produce agricultural goods, but are not intent on developing this into a larger business. Individuals in this category identified more instrumental rationales than their full-time counterparts, including "wanting a business," but intrinsic enjoyment of agricultural production was also identified. However, none of these respondents were investing in their farms with the intention of their children continuing the business.

Reluctant farmers, as implied in this distinction, are individuals producing agricultural goods for sale who would prefer to be deriving income from other sources, typically paid employment (5) or pension entitlements (2). As such, the distinction of this type is made primarily on the basis of objectives for farming. Although four respondents in this category were utilizing very small plots of land (household garden or 1-2 ha of restituted land), three of the respondents in this category held 14-18 ha. Two of these considered themselves "failed farmers," having been unable to successfully generate profits in earlier attempts at farming. They had reduced production to minimize losses and were actively seeking paid employment but without success. Reluctant farmers are typically involved in labor-intensive production of vegetables, dairy, and small numbers of livestock. They often focus on a specific commodity - in this study pork production was common - as the primary generator of additional income,

\footnotetext{
3 The term "pluriactive" was chosen to emphasize the non-farm employment of these respondents. The term "agribusinessman" was chosen to emphasise the non-farm businesses also owned and operated. Other uses of the term pluriactive could encompass both of these groups, but that is not the position taken in this paper.
} 
although the surplus from self-provisioning may also be sold. As could be expected, reluctant farms have no desire for their children to continue their farm operation.

One of the Bulgarian respondents is typologized as a "minority horticulturalist," to reflect the distinctive approaches to agricultural production adopted by members of some cultural minority groups in the study sites, in this case Roma. He is distinctive for producing tobacco on .1-.2 ha of rented land, a practice carried on from his parents. However, he estimated his parents' production as $80-90 \%$ higher than his own, as it was facilitated through contracts with the local cooperative farm. He lost his formal employment in the early 1990s and now undertakes construction work when it becomes available. As such, he resembles a reluctant farmer. His spouse is unemployed. He stated that he is not interested in agricultural production and would like his children to have their own lives, and not carry on the tobacco tradition.

The preceding categories represent idealized types: there were a few respondents who had elements of two types. For example, a farmer from Plovdiv region (Bulgaria) established a large-scale pig enterprise, with 12,000 sows and 100 employees. He does not fit the agribusiness category as defined, because he had no other businesses and a small land base. However, he was considerably larger scale than the primary farmers in the study. He also had not occupied an advanced position during the Soviet era, stating his work history to be truck driving. While this was a lucrative profession in the early 1990s, due to demand for trucking services, this is unlikely to explain that amount of resources evident in his pig operation, suggesting strong social ties. Similar to both agribusinessmen and primary farmers, he expressed an intrinsic interest in agricultural production and a desire for his children to carry on the business in future.

It is also important to note that the distinction of farmer types is not based on age. There were nine pensioners in the Bulgarian study, only two of which were classified reluctant farmers. Two of the younger pensioners were primary farmers, operating medium-scale farms; two others were pluriactive, maintaining paid employment and agricultural production despite official retirement. The other three clearly enjoyed producing agricultural goods in order to honor the heritage of their parents as private farmers. These three cannot be distinguished as hobby farmers, because they clearly benefit from the income generated by their actions; neither were they pluriactive, as they were not formally employed. As there were no similar approaches to farming identified in the Russian case study, they are treated as outliers rather than a distinctive type in this study. 
Russia

In Russia, agricultural land for private farming could be accessed through application to a government pool and/or through applying to release the land shares allocated to current or retired agricultural employees. As such, initial land holdings were considerably larger in Russia than Bulgaria. In this study, agricultural employees from Krimsk region received a minimum of 2 ha; agricultural employees from Pavlovsky received a minimum of 5 ha, but overall farm size ranged from 2 ha to 2000. The typology of Bulgarian farmers, based on scale and motivations, fits generally for Russian respondents, with some distinctions and proportions in the categories, which will be elaborated here.

Only one agribusinessman was found in the Russian study. This was an individual farming 2000 ha of rented land near Krimsk. Similar to the Bulgarian agribusinessmen, he has an additional business, an agricultural machinery dealership, which he had initiated prior to starting the farm. He appears to have an elevated social position, having worked as head engineer at a poultry factory. The farm produces grain, beans, soybeans, corn, and sunflower seeds and has an orchard. It employs 10 people. This respondent is also similar to Bulgarian agribusinessmen in actively planning for younger relatives (nephews, as he has no children) to continue after him in the business. He works in agriculture because he enjoys it, and expressed that although he would like family members to continue the farm, he recognizes that they may also want to pursue careers of interest to themselves.

Primary farming is much more common in Russia than Bulgaria, and 14 of the 25 Russian farmers were currently farming on a full-time basis, in that it was full-time work for the primary farmer, although his wife or other household members might be employed elsewhere. Typically, however, the spouse had been employed on the collective, and her land shares removed in order to establish a larger farm. Farms in this category ranged from nine ha to 195 ha, but were most commonly 60 - 70 ha. Similar to the Bulgarian study, farms typically comprised both rented and owned land, although more land was owned by the farmer than in Bulgaria. Farms usually had one to five employees or family members working on the farm. Two of the farms were former brigades, of six and ten men, who had withdrawn their land from the 
collective to start joint independent farms. Commodities produced included those of the agribusinessman above, but also watermelons, sugar beet, corn, hay, and potatoes. Similar to their Bulgarian counterparts, respondents identified primarily intrinsic and personal motivations for starting their farms, such as enjoying the work and being independent. However, they were mixed about whether they wanted their children to continue after them, some planning for it and others hoping that their children would choose jobs that are less work, more lucrative, and with more government support.

Pluriactive farming was found only among two of the Russian respondents, both of whom held full-time jobs. These farms were 5 ha and 17 ha of sunflowers and cereal crops. Both farmers had spouses with other employment, and neither wanted their children to work in agriculture. Both had worked in the collectivized agricultural system. Similar to Bulgarian pluriactive farmers, these farms were undertaken primarily to generate income, optimizing the available resource of land in the form of a farm business.

Only two reluctant farmers were interviewed in the Russian study, one pensioner supplementing her pension with extended home production and a couple having recently lost their jobs due to the bankruptcy of their privatized collective, who were starting a farm because there no other jobs available. Part of their allocation from the farm included a tractor (compensation for ten years of unpaid wages), and this was utilized to generate further income through contract work. Neither was planning for their children to continue the farm. Several former farmers were also identified in the study, largely through their participation in a different part of the study pool as agricultural employees. These individuals are notable for including a current privatized collective farm manager. This individual was unlikely to have failed at farming, and expressed a preference for management work. The other former farmers could be considered failed farmers, and had been successful in finding other work.

Three minority horiticulturalists were found among Russian respondents. These represent ethnic Korean and Turkish populations previously described in the social objectives section. Both were growing vegetables utilizing primarily manual labor on rented land. They were a regular feature at roadsides selling their produce in both study states. The scale of their operations varied from 1 ha for Turkish households, which tended to organize their work at the household or extended family level, to 15 or more ha for Korean households. The Korean interviewed was part of a 38 family brigade. Although both populations have been practicing 
agriculture in this form for several decades, it is difficult for future plans to be made, due to their uncertain residential status in the study sites. Both Turkish respondents indicated that young people seek agricultural employment either in country or abroad; the young Korean respondent indicated that he hoped to pursue factory work.

As was true of Bulgarian respondents, the typology presented is idealized, fitting most but not all of respondents. Similar to the Bulgarian study, there was an individual who met the criteria of both agribusiness and primary farming, by having both a store and a farm, but both businesses operating on a smaller scale than those of agribusinessmen. There was another respondent who had established an urban café at the same time as his farm, but this was disbanded due to economic difficulties in 1997, and household income is now entirely dependent on the farm. The ambitions of both farmers are for children to continue in the business.

\section{Discussion}

This paper has demonstrated the instrumental, intrinsic, social, and personal objectives of private farming in the study sites, utilizing these objectives in combination with structural characteristics of the associated farming operations to derive an idealized typology of approaches to private farming. This has resulted in the identification of several "new" kinds of private farmers, and the further analysis of the "entrepreneurial" and "subsistence" oriented characteristics already recognized in the EE literature. In this section, the implications of these emergent farming types for farm development and succession, and opportunities for future research are discussed.

The agribusinessmen found in this study are notable for the large scale of their farming operations, multiple business ownership, apparent social connections, orientation towards succession, and emphasis on personal and intrinsic as well as instrumental objectives in their decisions to become private farmers. Allina-Pisano (2004) described large-scale farmers in her Russian and Ukrainian study, but largely in reference to the importance of social connections to farm establishment. While this study is consistent with her findings, several issues arise from the further delineation of this population: the significance of multiple business ownership, the tradeoffs between personal, intrinsic, and instrumental motivations, and the link between personal and intrinsic motivations and objectives of farm succession. 
Multiple business ownership by farmers is not unusual in the West, particularly among large-scale farmers, as found by Carter (1999) in her UK study. She argued that the multiple holdings are important for the generation of rural employment, also a critical issue in post-Soviet regions. Although large-scale farmers cannot be expected to provide the degree of support to local services characteristic of privatized collectives or cooperatives, it was clear from this study that they consistently provide some form of support to local villages. This, in addition to employment creation, suggests that agribusinesses maybe fulfilling part of the social role previously assumed by state and collective farms. However, agribusiness development is not a panacea for rural development, particularly if these businessmen reinforce the informal relationships that assisted in their initial development. Trzeciak-Duval (1999) argues that agricultural policies cannot be effective in the absence of a well-functioning institutional structure and respect for the law. Agribusinessmen must be facilitated to engage in formal commercial and legal transactions if they are to play a positive role in rural development.

Agribusinessmen in this study also indicated that intrinsic and personal objectives associated with private farming are important to their decisions to initiate farms, and in some cases outweigh the greater economic returns possible from investing in other industries. The trade-offs between instrumental and other objectives were discussed in the findings section: farmers experiencing economic success are more likely to express the intrinsic and personal objectives of their farming operation. Coughenour (1995) argued that commitment to and satisfaction with farming are primarily contingent on the intrinsically rewarding aspects of farm work. Both agribusinessmen and primary farmers are remarkable for consistently expressing intrinsic and personal interests in agricultural production and also in integrating their children into their businesses, suggesting a connection between the two objectives. Pluriactive farmers are notable for expressing neither of these goals: they express primarily instrumental objectives for their farms, with no interest in succession. The question of how these objectives arise is therefore important to the future development of private farming in the study states.

The historic resilience of family farming is attributed to the willingness of farm families to work flexible hours and absorb periodic economic losses in order to maintain control of their land (Friedmann 1980). Burton (2004) and Gray (1998) have demonstrated how cultural values of farming come to be embedded in farming culture and passed through generations. However, although observing parents was identified as important to the development of intrinsic 
motivations, study site farmers who have identified successors are not those who have an active family heritage of private farming. Instead, they represent a collection of individuals who initiated private farms for a wide variety of reasons, inevitably influenced by Soviet-era experiences, and now operating in global markets and subject to global cultural influences. In addressing the question of declining numbers of successors in the West, Villa (1999) in a Norwegian study argued that the choice and individualism characterizing modernity have gradually infiltrated values in farming populations, and as a result young people pursue farming in order to fulfill personal ambitions, not as the default position of growing up on a farm. Farm children in the West have routine access to higher education and opportunities to observe the "nine to five" lifestyles possible through non-farm employment. The same is now true of rural children in EE, and commonly expressed in this study in the form of parental desires for children to achieve outside of the agricultural sphere in work that is less arduous and higher paying. A degree of self-actualization can thus be expected to be part of commitment to private farming. However, the stigma currently associated with rural life, particularly in Bulgaria, can be expected to weigh against private farming as a life choice for next generation farmers, unless significant improvements are made to rural quality of life.

Primary farmers identified in the study expressed instrumental, intrinsic, and personal objectives associated with their farms. Unlike agribusinessmen and pluriactive farmers, private farmers are highly dependent on farming as a source of household income, and thus are highly vulnerable to market and policy shifts, as are reluctant farmers and minority horticulturalists. However, primary farmers tend to operate larger farms than reluctant farmers and minority horticulturalists, and often identify succession as a goal. Positive attitudes towards succession are consistent among Bulgarian primary farmers, whereas Russian primary farmers expressed mixed views. This is most likely due to the much higher level of political support for private farming in Bulgaria, where private farming is much more common. In Krasnodar Territory, institutional processes favor privatized collective farms, to the degree that Krasnodar has only half the relative number of private farmers as neighboring Stavropol Territory (Pallot and Nefedova 2007). This demonstrates the influence of regional policies on agrarian structural change in general. Key informants also identified a $75 \%$ failure rate for private farmers in Krasnodar Territory, indicating that farm establishment is high risk, even with informal connections to access land. Failure rates are less easy to determine in Bulgaria, where registration as a private 
farmer is voluntary, and pluriactivity more common, making it difficult to define "real farms" and thus their failure. The higher level of reluctance toward succession in Russia appears due to lack of government support, rather than differences in farmer objectives.

Study findings demonstrate the range of scales at which the desire to "have a business" can be expressed. While this could be expected among large-scale producers - Western farming typologies typically include an agribusiness (Shucksmith and Hermann 2002) or entrepreneurial (Salamon 1985) category addressing large, expanding farms - small-scale farms are not typically found in these categories. In this study, small-scale pluriactive farmers seek to optimize returns from the land resource available to them in addition to paid employment. This represents a fundamental difference from how pluriactivity typically presents in the West.

The Western farming literature suggests that pluriactivity is more common than full-time farming in Europe, representing 60\% of farms (Bryden et al. 1992). In this sense, pluriactivity is not an unexpected finding in EE, where multiple job holding is a long-term phenomenon in rural areas (Swain 1999). However, whereas small-scale farming in the study sites is undertaken to generate additional income, in the West, formal employment is often undertaken to increase household income, while maintaining the benefits of private farming, such as being your own boss and carrying on family heritage (Bartlett 1986). Part-time farming in the West can also be a means of transitioning into or out of farming full-time, whereas most pluriactive farmers in this study expressed no desire to increase or decrease the scale of their farm operation. In this study, pluriactive farmers typically expressed instrumental orientations to their farm, viewing it primarily as an income generating activity, although they may also enjoy the work. This raises the question of the degree to which study site pluriactive farmers can be considered entrepreneurs.

Vesala et al. (2007) describe three primary characteristics of entrepreneurship: undertaking calculated economic risk, aiming for business growth, and undertaking innovative markets and methods. Formal market assessments prior to initiating production were only identified by three respondents, all of whom had multiple businesses, but none of whom were classified pluriactive. Alternately, the degree of innovation appears to increase with decreasing farm scale: the largest farmers produce commodities similar to those of collective agriculture, the smallest experiment with niche crops such as lavender and watermelons. However, these largely pluriactive farmers are notable for expressing no interest in business expansion. Instead, they are 
seeking a business within a limited allocation of resources and time. Entrepreneurship can be considered problematic among Western farmers, due to questions about whether as farm business owners they constitute entrepreneurs, a position taken by Carter (1999). Historically family farming was focused around producing rather than marketing commodities. As a result, family farmers tend to see themselves as food producers rather than businessmen, although with decreasing market returns, skills in marketing and management are increasingly important and often the subject of agricultural extension measures (de Wolf et al. 2007). Private farmers in EE appear more entrepreneurial by having had to initiate (rather than inherit) their farm business, and the immediate need to respond to market pressures. This suggests a much stronger market orientation and responsiveness in EE than for Western family farmers. Further research in this area could assist in identifying entrepreneurial and business skills and how these have developed among the new EE private farmers.

It is self-evident from the description of objectives for farming that "reluctant farmers" would gladly take paid employment or retire as soon as it became economically feasible. Clearly, should the rural or indeed urban economies improve in both study states, the number of reluctant private farmers could be expected to reduce dramatically. Kopeva et al. (2003), in their Bulgarian study, identified this as a primary reason for transition out of private farming. The question of longevity is more interesting among other producer types. It is well accepted in the Western family farming literature that farmers with identified successors are much more likely to be investing in and developing their farms, resulting in a more viable farming business. Both agribusinessmen and primary farmers typically identified succession as an important goal, although this was more common in Bulgaria than Russia.

The phenomenon of short-term farming is a new issue for private farming. Farms in the West are typically passed between generations, a feature that is commonly included in definitions of family farming (e.g., Gasson and Errington 1993). Pluriactive farmers in this study are uniformly not aiming for family succession. Would these individuals also give up their farming enterprise in an improved economic climate, or would their carry on with their "business," and at what scale? Would long term investment in a small-scale operation lead to intrinsic or personal objectives, and thus impact on expansion or succession plans? Does the successful initiation of a small-scale farm business lead to further entrepreneurship? These are topics for further study. 
A type commonly identified in typologies of Western farming notably missing from this study is hobby farming: farming for recreational purposes. Pallot and Nefedova (2003) found evidence of this approach among small-scale producers in Russia, describing a long-term culture of recreational gardening. Three of the Bulgarian pensioners also expressed largely intrinsic and personal motivations for their small-scale production, although they were also dependent upon it for income. This raises issues of evolving social norms: as private farming becomes a longerterm phenomenon, and ceases to be a novelty, new social expectations can be expected to emerge. Although private farming currently appears to represent a "break" from local society, as this becomes a longer-term phenomenon, local attitudes may shift. Long-term, hobby farming may not be limited to small-scale production, but expand to include larger holdings - potentially those of individuals with multiple successful businesses.

Minority horticulturalists have not been addressed to any degree in this discussion. This reflects the small number of respondents in the study, and the relatively limited literature currently available on the subject. The evolution and viability of these groups, with their laborintensive production practices coexisting with mechanized agrarian systems, is worth observing.

This study has also not addressed the issue of gender in relation to private farming. This is because the number of female farmers in the study was too small to be able to draw conclusions. It has been demonstrated in the literature on $\mathrm{EE}$ that women were often disadvantaged by the post-Soviet reforms, due to employer preferences for hiring and retaining male employees (Pollert 2003). Allina-Pisano (2004) reported stories of violence and intimidation described by female farmers. In this study, there were female respondents among the primary, pluriactive, and reluctant farmer categories, with key informants indicating that there are large-scale female renters (therefore possibly agribusinesswomen) in Bulgaria and female minority horticulturalists. This suggests that women farmers can be expected to approach farming in as many different ways as their male counterparts. Many of the farmers in the study also had wives or daughters involved in the farming operation. The satisficing principle of farmer decision-making described earlier is based on the consideration of multiple household (rather than individual) goals. Internal dynamics of the farm household thus play an important role in farm decision making, but were beyond the scope of this study. The evolving gender roles of women in farming in EE, as well as dynamics internal to the farm household, are useful areas for further research. 


\section{Limitations}

The study findings are drawn from a case study of four sites in Bulgaria and southern Russia. Although the range of types is extensive, it is not appropriate to speculate on the relative economic viability or prevalence of the different types due to the nature of study data. Further quantitative research could usefully be based on this research, in order to establish the prevalence and consistency of the types represented and to further explore commercial issues such as degree of formal market integration, which has been utilized in farmer differentiation in the West (Whatmore et al. 1997a, 1997b). In line with this, key informants to the study were utilized primarily to provide background context and comparison for farmer respondent statements about objectives and farm characteristics; further interaction with key informants could provide useful information on institutional development coinciding with the emergence of specific farming types in different geographic and political regions.

The cultural differences between Russia and Bulgaria have not been elaborated to any degree in this paper. This largely reflects the quality of data collected through a translator and transcribed in note form in Bulgaria. Stated objectives for starting and maintaining private farms can be expected to be considerably more nuanced than they are presented in this paper. To date, the anthropological work in EE has provided useful insights into the development of small numbers of farms in specific villages. Further qualitative work could usefully focus on private farmers across broader geographic regions, developing the farming objectives presented in this paper, to further illuminate cultural sources and distinctions.

\section{Conclusion}

The West has an extensive body of literature demonstrating that household objectives influence differential farm development and therefore responses to policy initiatives and market shifts. In this paper the author has sought to open up some of these areas for discussion in the EE context. Findings are an important contribution to the study of post-Soviet "agrarianism" - defined as the 
"ideology of those involved in agriculture" (Beus and Dunlap 1994, p. 462), adding to studies of agricultural manager and employee rationales (Sutherland 2008) and home producers (Brown and Kulcsar 2001; Pallot and Nefedova 2007). Agrarianism in the US is traced back to Thomas Jefferson, and his construction of agriculture as the basic industry, the farmer as self-sufficient and therefore independent, and farm life as natural and good (Dalecki and Coughenour 1992). Both Bulgaria and Russia have extensive agrarian heritages, but stemming from histories of largely collective rather than individual agricultural production. Even within the US, agrarianism is not consistently defined, with different aspects of farming: production, moral excellence, and farming as a way of life emphasized by different groups (Beus and Dunlap 1994). The evolving agrarianism of post-Soviet states provides a rich ground for testing of Western concepts of agrarian change and formation of new theories surrounding the establishment and evolution of agrarian forms.

\section{Acknowledgements}

The author wishes to thank the Social Sciences and Humanities Research Council of Canada and the Macaulay Land Use Research Institute for funding the study and the analysis presented in this paper. The author also thanks Stela Valchovska for facilitating access to Bulgarian resources and three anonymous reviewers for their constructive comments on an earlier draft of this paper.

\section{References}

Allino-Pisano, J. 2004. Land reform and the social origins of private farmers in Russia and Ukraine. Journal of Peasant Studies 31 (3-4): 489-514.

Atlas Mira (World Atlas). 2001. Moscow: Izdatelsctvo ACT.

Bartlett, P. 1986. Part-time farming: Saving the farm or saving the lifestyle? Rural Sociology 51(3): 289-313.

Beus, C.E., and R.E. Dunlap. 1994. Endorsement of agrarian ideology and adherence to agricultural paradigms. Rural Sociology 59(3): 462-484. 
Bezemer, D.J. 2002. De-collectivization in Czech and Slovak agriculture: An institutional explanation. Journal of Economic Issues 36(3): 723-745.

BNSI (Bulgarian National Statistical Institute). 2003. Statistical Yearbook. Sofia: Bulgarian National Statistical Institute.

Bowler, I., G. Clark, A. Crockett, B. Ilbery, and A. Shaw. 1996. The development of alternative farm enterprises: A study of family labor farms in the Northern Pennines of England. Journal of Rural Studies 12 (3): 285-295.

Brown, D.L., and L. Kulcsar. 2001. Household economic behavior in post-socialist rural Hungary. Rural Sociology 66(2): 157-180.

Bryden, J.M., C. Bell, J. Gilliatt, E. Hawkins, and N. MacKinnon. 1992. Farm household adjustment in Western Europe 1987-1991. Vol. 1 and 2. The Arkleton Trust (Research) Ltd, Nethy Bridge.

Bryman, A. 2001. Social research methods. Oxford: Oxford University Press

Burton, R. 2004. Seeing through the "good farmer's" eyes: Towards developing an understanding of the social symbolic value of "productivist" behavior. Sociologia Ruralis 44(2): 195-215.

Carter, S. 1999. Multiple business ownership in the farm sector: Assessing the enterprise and employment contributions of farmers in Cambridgeshire, Journal of Rural Studies 15(4): 417-429.

Caskie, P. 2000. Back to basics: Household food production in Russia. Journal of Agricultural Economics 51(2): 196-209.

Chevalier, S. 2001. Spheres of exchange in the Bulgarian transition. Max Planck Institute for Social Anthropology, working paper no. 24. Halle, Germany: Max Planck Institute.

Clarke, S., L. Varshavskaya, S. Alasheev, and M. Marelina 2000. The myth of the urban peasant. Work, Employment, and Society 14(3): 481-499.

Coughenour, C.M. 1995. The social construction of commitment and satisfaction with farm and nonfarm work. Social Science Research 24: 367-389.

Dalecki, M.G., and C.M. Coughenour. 1992. Agrarianism in American society. Rural Sociology 57(1): 48-64.

Davydova, I., and J.R. Franks. 2006. Responses to agrarian reforms in Russia: Evidence from Novosibirsk oblast. Journal of Rural Studies 22(1): 39-54. 
de Wolf, P., G. McElwee, and H. Schoorlemmer. 2007. The European farm entrepreneur: A comparative perspective. International Journal of Entrepreneurship and Small Business 4(6): 679-692.

Dobreva, S. 1994. The family farm in Bulgaria: Traditions and changes. Sociologia Ruralis 34(4): 340-353.

Ellman, M. 2003. Expectations and reality: Reflections on a decade of agricultural transformation. In Transition, Institutions, and the Rural Sector, ed. M. Spoor, pp. 1-3 Oxford: Lexington Books.

Federal Office of State Statistics. 2006. Division of agricultural harvest by land use type. http://www.gks.ru/bgd/regl/b08_11/IssWWW.exe/Stg/d02/15-01.htm. Accessed 10 February 2008.

Friedman, H. 1980. Household production and the national economy: Concepts for the analysis of agrarian formations. Journal of Peasant Studies 7: 2.

Gambold-Miller, L.L. 2003. Interdependence in rural Russia: The post-socialist mixed feudal economy. Max Planck Institute for Social Anthropology, working paper no. 51, Halle, Germany: Max Planck Institute.

Gasson, R. 1973. Goals and values of farmers. Journal of Agricultural Economics 24: 521-542.

Gasson, R., and A. Errington. 1993. The farm family business. Wallingford: CAB International.

Goskomstat of Russia. 2002. Krasnodar Krai 1937-2002. Krasnodar, Russia: Krasnodar Territorial Committee of Government Statistics.

Gray, J. 1998. Family farms in the Scottish borders: A practical definition by hill sheep farmers. Journal of Rural Studies 14(3): 341-356.

Hivon, M. 1998. The Bullied farmer. Social pressure as a survival strategy? In Surviving postsocialism. Local strategies and regional responses in Eastern Europe and the former Soviet Union, ed. S. Bridger and F. Pine, pp. 33-51. London: Routledge.

Howden, P., and F. Vanclay. 2000. Mythologization of farming styles in Australian broadacre cropping. Rural Sociology 65(2): 295-310

Ioffe, G., and T. Nefedova. 1997. Continuity and change in rural Russia: A geographical perspective. Boulder, Colorado: Westview Press. 
Kalugina, Z. 2002. Adaptation strategies of agricultural enterprises during transformation. In Rural reform in post-Soviet Russia, ed. D.J. O'Brien and S.K. Wegren, pp. 367-384. London: The Johns Hopkins University Press.

Kaneff, D. 1998. Private co-operative and local property relations in rural Bulgaria. Replika: Hungarian Social Science Quarterly (Special Issue): 161-172.

Kitching, G. 1998. The revenge of the peasant? The collapse of large-scale Russian agriculture and the role of the peasant "private plot" in that collapse, 1991-1997. Journal of Peasant Studies 26(1): 43-81.

Kopeva, D., J. Doichinova, S. Davidova, M. Gorton, H. Chaplin, and D. Bezemer. 2003. Rural households, incomes, and agricultural diversification in Bulgaria. In Transition, institutions, and the rural sector, ed. M. Spoor, pp. 103-122. Oxford: Lexington Books.

Kostov, P., and J. Lingard. 2002. Subsistence farming in transitional economies: Lessons from Bulgaria. Journal of Rural Studies 18(1): 83-94.

Leonard, P., and D. Kaneff. 2002. Introduction. In Post-socialist peasant? Rural and urban constructions of identity in Eastern Europe, East Asia, and the former Soviet Union, ed. P. Leonard and D. Kaneff, pp. 1-43. New York: Palgrave.

Lerman, Z. 2003. A decade of transition in Europe and Central Asia: Design and impact of land reform. In Transitions, institutions, and the rural sector, ed. M. Spoor, pp. 5-26. Lexington: Oxford Books.

Lerman, Z., C. Csaki, and G. Feder. 2004. Agriculture in transition. Land policies and evolving farm structures in post-Soviet countries, Oxford: Lexington Books.

Long, N. 2001. Development sociology. Actor perspectives. London: Routledge.

Long, N. 1997. Agrarian change, neoliberalism, and commoditization. A perspective on social value. In Images and realities of rural life, ed. H. de Haan and N. Long, pp. 226-244. Wageningen Perspectives on Rural Transformations. Assen, Netherlands: Van Gorcum \& Co.

Marsden, T., R. Munton, and N. Ward. 1992. Incorporating social trajectories into uneven agrarian development: Farm businesses in upland and lowland Britain. Sociologia Ruralis 32(4): 408-430.

Mason, J. 2002. Qualitative researching. Second ed. London: Sage. 
Meurs, M., and S. Djankov. 1998. The alchemy of reform. Bulgarian agriculture in the 1980s. In Privatizing the land. Rural political economy in post-communist societies, ed. I. Szelenyi, pp. 43-61. London: Routledge.

Noon, M., and P. Blyton. 2002. The realities of work. 2nd ed. New York: Palgrave.

NSPRD (National strategy plan for rural development, Republic of Bulgaria). 2007. 2007-2013. The European agricultural fund for rural development. http://www.mzgar.government.bg/MZ_eng/OfficialDocuments/Programs/programs.htm. Accessed 10 February 2009.

O'Brien, D.J., and V. Patsiorkovski. 2006. Measuring social and economic change in rural Russia. Surveys from 1991 to 2003. Rural Economies in Transition Series, Oxford: Lexington Books.

Pallot, J., and T. Nefedova. 2007. Russia's unknown agriculture. Household production in postcommunist Russia. Oxford Geographical and Environmental Studies Series. Oxford: Oxford University Press.

Pallot, J., and T. Nefedova. 2003. Trajectories in people's farming in Moscow Oblast during the post-socialist transition. Journal of Rural Studies 19(3): 345-362.

Pollert, A. 2003. Women, work and equal opportunities in post-communist transition. Work, Employment, and Society 17(2): 331-357.

Rubin, H.J., and I.S. Rubin. 1995. Qualitative interviewing. The art of hearing data. London: Sage.

Salamon, S. 1985. Ethnic communities and the structure of agriculture. Rural Sociology 50(3): $323-340$.

Shucksmith, M., and V. Herrmann. 2002. Future changes in British agriculture: Projecting divergent farm household behavior. Journal of Agricultural Economics 53(1): 37-50.

Simon, H.A. 1957. Models of man: Social and rational. London: John Wiley \& Sons.

Small, L.-A. 2007. East meets West: Utilizing Western literature to conceptualize post-Soviet agrarian change. Journal of Peasant Studies 34(1): 29-50.

Small, L.-A. 2005. The influence of "family" on agrarian structure: Revisiting the family farm debate in Bulgaria and southern Russia. Journal of Comparative Family Studies 34: 527543. 
Spoor, M., and O. Visser. 2004. Restructuring postponed? Large-farm enterprises "coping with the market." Journal of Peasant Studies 31(3/4): 515-551.

Sutherland, L.-A. (née Small). 2008. Post-Soviet agricultural employment: A case study of employee incentives in Krasnodar Territory, Russia. Journal of Peasant Studies 35(3): 369389.

Swain, N. 2000. The rural transition in post-Central Europe and the Balkans. Max Planck Institute for Social Anthropology, working paper no. 9. Halle, Germany. http://www.eth.mpg.de/.

Swain, N. 1999. Conceptualizing late modernity as a shock. Paper presented to Working Group 6 at the $18^{\text {th }}$ Congress of the European Society for Rural Sociology, Lund, Sweden.

Trzeciak-Duval, A. 1999. A decade of transition in central and eastern European Agriculture. European Review of Agricultural Economics 26(3) 283-304.

van der Ploeg, J.D. 1994. Styles of farming: An introductory note on concepts and methodology. In Born from within: Practice and perspectives of endogenous rural development, ed. J.D. van der Ploeg and A. Long, pp. 7-30. Assen, Netherlands: Van Gorcum.

Vesala, M.M., J. Peura, and G. McElwee. 2007. The split entrepreneurial identity of the farmer. Journal of Small Business and Enterprise Development 14(1): 48-63.

Villa, M. 1999. Born to be farmers? Changing expectations in Norwegian farmers' life courses. Sociologia Ruralis 39(3): 328-342.

Wegren, S., and V.R. Belen'kiy. 2002. Change in land relations: The Russian land market. In Rural reform in post-Soviet Russia, ed. D.J. O’Brien and S.K. Wegren, pp. xxx. London: The Johns Hopkins University Press.

Wegren, S.K., D.J. O’Brien, and V.V. Patsiorkovski. 2002. Winners and losers in Russian agrarian reform. Journal of Peasant Studies 30(1): 1-29.

Whatmore, S., R. Munton, T. Marsden, and J. Little. 1987a. Towards a typology of farm businesses in contemporary British agriculture. Sociologia Ruralis 27(1): 21-37.

Whatmore, S., R. Munton, T. Marsden, and J. Little. 1987b. Interpreting a relational typology of farm businesses in southern England. Sociologia Ruralis 27(2): 101-122. 


\section{Appendix A: Code headings for livelihood profiles}

Country

Date and location of interview

Gender

Age

Educational achievement

Current occupation

Work history

Parents worked in agriculture?

Children work in agriculture? (includes succession plans)

Land relations (size of holdings, owned or rented)

Livelihood (sources of household income)

Future orientation (plans for self and farm)

Personal motivations (for farming and/or other businesses)

Problems (biggest problems in past 10 years)

Agricultural opinions (what would need to happen for agriculture to improve)

What is a good farmer?

Innovation or risk (evidence of these behaviors)

Success (degree to which respondent has had a positive post-Soviet experience)

Agrarian identification (identification of self as farmer, peasant, businessman, other)

Personal change factors (which issues have been most important for the employment decisions which have been made)

Other (number of employees, structure of business, details of production) 
Figure 1. Study Site Locations

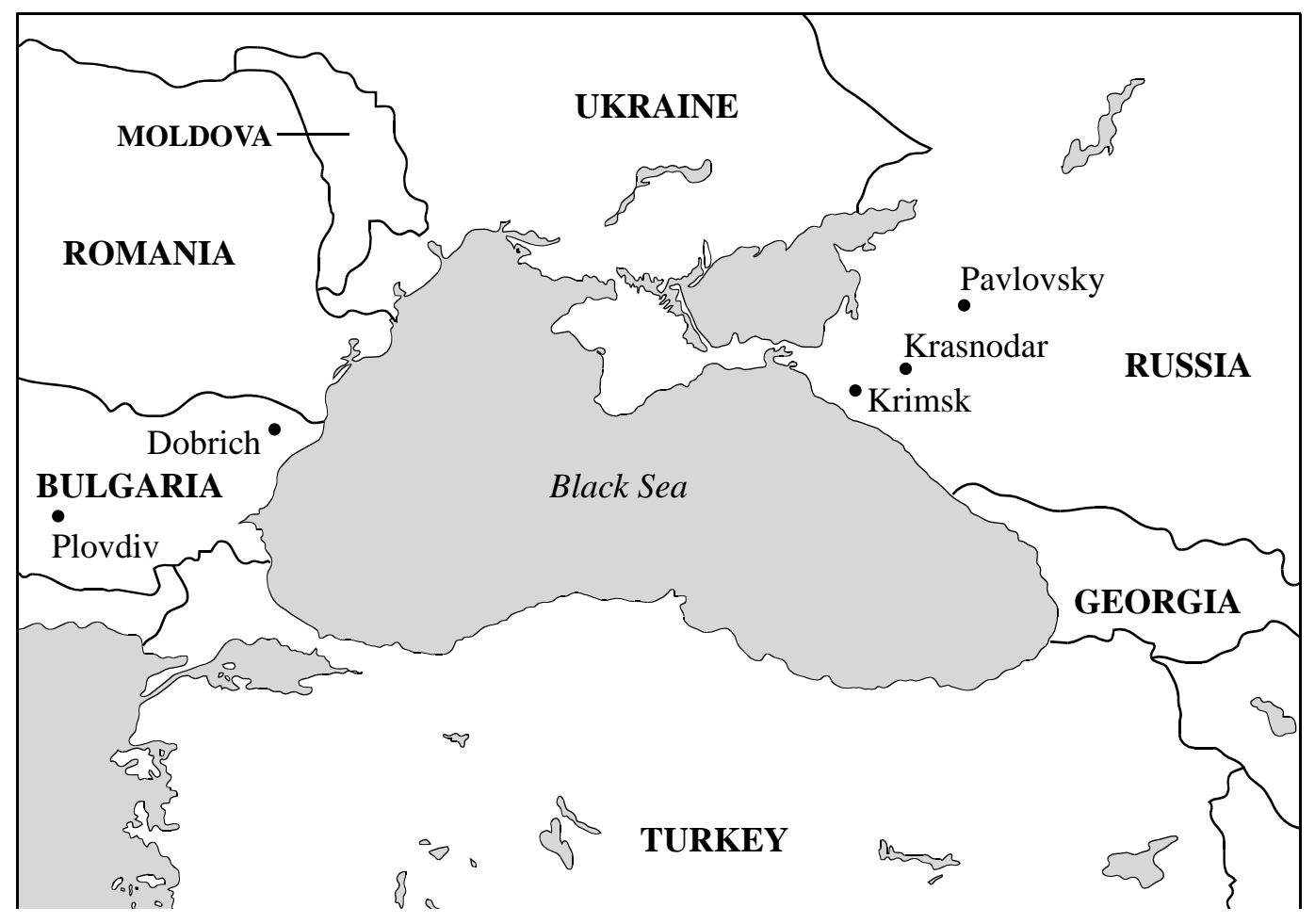

Source: Atlas Mira, 2001 